\title{
LA COFRADÍA-GREMIO DURANTE LA BAJA EDAD MEDIA Y SIGLOS XVI Y XVII, EL CASO DE LA COFRADÍA DE CIRUJANOS, BARBEROS, FLEBOTOMIANOS Y MÉDICOS EN ESPAÑA Y LA NUEVA ESPAÑA
}

\author{
THE BROTHERHOOD-GUILD DURING THE LATE MIDDLE AGES AND \\ 16th AND 17th, CENTURIES THE CASE OF THE BROTHERHOOD OF \\ SURGEONS, BARBERS, PHLEBOTOMISTS AND DOCTORS IN SPAIN \\ AND THE NEW SPAIN
}

\author{
María Luisa Rodríguez-Sala Gomezgil \\ Universidad Nacional Autónoma de México. México/Mexico \\ rsala@servidor.unam.ex
}

Recibido/Received: 14/05/09

Aceptado/Accepted: 12/08/09

\section{RESUMEN}

Las cofradías y los gremios constituyen tipos de asociaciones voluntarias difícilmente distinguibles. El gremio y/o la cofradía surgieron como necesidad de asociación de artesanos, mercaderes y profesionales quienes buscaron defender sus intereses laborales frente a la intrusión de extraños y gente no debidamente preparada. Su aparición durante la Alta Edad Media y su auge durante la Baja explican su estrecha vinculación con tareas religiosas, ya que la vida social de esos escenarios temporales estaba permeada totalmente por la religión. De ahí que en este artículo planteemos como hipótesis de trabajo la simbiosis entre ambas y propongamos como su designación la de cofradíagremio, Se estudian las cinco etapas de su desarrollo, algunas de sus características para pasar después a describir su aparición en España y terminar con el aspecto que corresponde a la cofradía de San Cosme y San Damián en la que se agruparon los médicos, cirujanos, barberos, flebotomianos y boticarios, pero sólo como una cofradía sin tener el elemento gremial. En la última parte se pasa al estudio comparativo de las características que asumió este tipo de asociación voluntaria en la Nueva España y se destaca la pervivencia de las cofradías en algunas ciudades, con especial énfasis en la de San Cosme y San Damián.

\section{PALABRAS CLAVE}

Gremio, cofradía, cofradía-gremio, Alta Edad Media, Baja Edad Media, España, Nueva España, San Cosme y San Damián.

\begin{abstract}
Brotherhoods and guilds are types of voluntary associations hardly distinguishable from one another. Guilds and brotherhoods emerged as necessary craftsmen's associations, merchants and professionals looking for the defense of their trading interests in the face of encroachment by aliens and unqualified individuals. Their emergence during the High Middle Ages and the Low Middle Ages explain their tight loyalty to religious commitments, since the social life of those materialistic scenarios was totally influenced by religion. In this article we raise as a working hypothesis the study of the symbiotic relationship between both and we propose the concept of brotherhood-guild to design them. The five stages in their development are studied, some of their features, and later we
\end{abstract}


portray their emergence in Spain, finally dealing with the question corresponding to the San Cosme and San Damian brotherhood, where physicians, surgeons, barbers, phlebotomists and pharmacists were joined together just as a brotherhood without the elements of the guild. In the final part I make a comparative study of features assumed by this type of voluntary association in New Spain, and pinpoint the survival of brotherhoods in some cities, specially the one of San Cosme and San Damian, aswell as the devotion to these two saints.

\section{KEYWORDS}

Guild, Brotherhood, Brotherhood-guild, High Middle Ages, Low Middle Ages, Spain, New Spain, San Cosme, San Damian.

\section{GENERALIDADES SOBRE EL DESARROLLO DE LA COFRADÍA-GREMIO}

Durante la Baja Edad Media los miembros de los grupos de artesanos, comerciantes y algunas profesiones que requerían, en una forma u otra, el trabajo manual, se agruparon o hermanaron para la protección de sus intereses laborales. Fueron el resultado de la ausencia del derecho individual y de la imposibilidad de realizar trabajo aislado o independiente. Quienes no pertenecían a una institución fuerte como la Iglesia o la Universidad tuvieron, desde el siglo XI, que asociarse libremente para ejercer su trabajo con una cierta garantía en el pago de sus salarios o en la venta de sus productos. El interés político no estuvo exento en su desarrollo, la necesidad de los poderes municipales para regular los precios de los productos y los pagos de ciertas tareas artesanales o manuales, así como la intrusión de artesanos o mercaderes externos, estuvo presente durante los años iniciales.

Según la Enciclopedia Internacional de las Ciencias Sociales el estudio de los gremios constituye uno de los lazos más estrechos entre las ciencias sociales, diría yo, la sociología y la historia. La primera, en realidad, los considera como una expresión de las asociaciones voluntarias y los estudia desde su papel en la evolución de las sociedades, ${ }^{1}$ pero sin mención a la indiscutible presencia de la cofradía. Según esa fuente el desarrollo del gremio se dio en cinco etapas. Cubren, desde su surgimiento en los reinos "bárbaros" del Norte hacia el siglo XI hasta su extinción en gran parte de Europa a mediados del siglo XIX, con el nuevo desarrollo industrial y la caída en desuso del sistema de privilegios que llegaron a representar los gremios y las cofradías. Las fases intermedias están vinculadas con la fuente de legitimidad de la asociación. En la fase segunda, ésta se manifiesta independiente de las primitivas y débiles monarquías, pero al fortalecerse se declaran como la fuente de legitimidad de la asociación. La otra gran fuerza del poder medieval, el Papado hace lo mismo con las órdenes religiosas, pero permite la libre formación de la cara religiosa del gremio, la cofradía seglar, casi siempre formada por los agremiados. En ella se conserva la libertad de asociación, pero, desde luego, bajo la protección de la Iglesia y particularmente de ciertos santos, seleccionados por cada cofradía, por su similitud de actividades. La unión entre el gremio y la cofradía se manifiesta en la característica parroquial del primero.

En esa segunda fase resulta ya difícil distinguir entre las atribuciones del gremio y las de la cofradía. Bien podemos decir que el primero es la expresión laica que no se disocia de la religiosa, la cofradía; se simbiotiza con ella y marchan unidas en sus tareas sociales, siempre al amparo de las acciones religiosas. Como dice Santiago Cruz, "los 
obreros, diríamos, los artesanos, se agrupan, por la fe, en las cofradías y por la ley en los gremios". ${ }^{2}$ Si bien la cofradía es el complemento del gremio y viceversa, también sucede que puede haber cofradía sin gremio, y, probablemente, también llegar a existir éste sin la primera. Sin embargo, esta segunda opción es mucho más dudosa, ya que, como hemos apuntado, la religión permeaba todo aspecto de la vida medieval y renacentista.

Según los autores que se han ocupado del estudio de los gremios, los primeros que aparecieron en la historia medieval asumieron la categoría de cofradías religiosas. Es entendible esta conformación si aceptamos que durante la Baja Edad Media y aún en etapas históricas sucesivas, la religión estaba presente, era omnímoda en todos los aspectos de la vida cotidiana. No era entendible, aceptable, ni posible, ejercer fuera de la unión o vinculación con la Iglesia. Ésta otorgaba poder y apoyo a las asociaciones que a ella se acogían, de aquí que los primeros gremios de artesanos y profesionistas surjan como cofradías en estrecha simbiosis con la estructura religiosa. Pero, en una aproximación más profunda, es difícil discernir y establecer cuál de las dos asociaciones voluntarias surge primero. Hasta dónde llegaron ambos términos a ser equivalentes es difícil establecer, ya que desde la Baja Edad Media los encontramos unidos; sin embargo, con mucha mayor frecuencia expresados como cofradías. De aquí que optemos en este trabajo en nominarlos como cofradías-gremios, anteponiendo el primer término en obsequio a una prelación cronológica. Esta hipótesis la encontramos confirmada en un buen trabajo sobre los gremios, en él su autor, Recio Lamata, asienta que "ambos tipos de corporaciones coexistieron y fueron un mismo cuerpo en muchos casos, sin saber distinguir hasta donde llegaba el gremio y donde empezaba la cofradía por lo que se habla frecuentemente de cofradía-gremial". $3^{2}$

Durante la etapa tercera se da paso al surgimiento de una clara diferenciación entre los diferentes gremios y/o cofradías. Una vez pasada la etapa de las invasiones, la migración urbana interna y externa permite y facilita el crecimiento de las ciudades. Este hecho, obliga a que sus ciudadanos se aglutinen en torno a sus diferentes actividades laborales. Después de los doscientos años de expansión mercantil que representaron los siglos XI y XII, en los siguientes tres, las ciudades y sus artesanos cobraron conciencia de su situación oprimida y de la necesidad de hacer valer su derecho a trabajar libremente. El artesano o el profesional es pobre y carece de poder, pero reclama ya privilegios para protegerse de la intrusión de extranjeros o de improvisados que ofrecían mercancías o servicios poco convenientes. Para evitar estas contingencias peligrosas para su subsistencia, los trabajadores citadinos aceptan unirse cada vez en mayor número de asociaciones, siempre de acuerdo, a la misma artesanía o actividad.

El control de precios, de mercancías y salarios recayó cada vez más en las ciudades, quienes tomaron el relevo de manos de los señores feudales. Surge así el poder de los municipios que va asociado con las cofradías-gremios, ya que unos y otros, buscan mantener el orden citadino. Las ciudades y sus municipios crecen al unísono que las asociaciones voluntarias.

Éstas, sean sólo religiosas, cofradías, sean religiosas y laicas, cofradías-gremios, traen consigo la vigilancia de la actividad basada en su adecuado manejo. La adquisición progresiva de habilidades y conocimientos dentro del gremio es una de sus características esenciales de organización y funcionamiento jerárquicos. Como bien sabemos, los "aprendices" trabajaban sin salario durante un número variable de años, según el gremio, en el taller o tienda del "maestro" en donde, además de conocimientos recibían casa y alimentos. Una vez adquirida la instrucción, el "aprendiz" pasaba a ser "oficial” y si lo 
deseaba se separaba y trabajaba por su cuenta con un salario estipulado por las ordenanzas del gremio, pero siempre bajo la vigilancia del "maestro". Éste era el dueño del lugar del trabajo y de los instrumentos. Se accedía a la máxima categoría después de haber demostrado su capacidad, mediante la realización de una "obra maestra" en el caso de los artesanos. En el de los profesionales manuales, los que interesan a este trabajo, como los barberos, flebotomianos, farmacéuticos y cirujanos, era requisito indispensable contar con la experiencia probada durante largo tiempo bajo la supervisión de un médico o un cirujano examinado. En el caso de las profesiones agremiadas generalmente se ganaba el título de "maestro", cuando se había presentado un examen ante los tribunales de control, donde éstos existían, o bien ante los mismos integrantes jerárquicamente más elevados del gremio o cofradía. No era fácil llegar a la máxima jerarquía, ya que, por lo general, los "maestros", como los médicos, no deseaban competencia o bien, la controlaban según las necesidades sociales de cada ciudad. Las mujeres no participaban dentro de las cofradíasgremios, si bien sí eran sus beneficiarias, a través de las ayudas familiares que emanaban de la pertenencia a ese tipo de organización. Así las viudas de un "maestro" podían conservar el taller o tienda, siempre con la ayuda de otros "maestros", quienes voluntariamente la apoyaban, pero, desde luego, no disfrutaban de la categoría de "maestras" y por lo tanto, no podían tener aprendices a su cargo.

Los años de los siglos XI a XV se caracterizan en toda Europa por el establecimiento dentro de las cofradías-gremios de sus ordenanzas o estatutos. Los normados se inician, siglos XI y XII, principalmente en el Norte de Francia, Alemania y Flandes y desde ahí se trasladan a Inglaterra, al Sur de Francia y a través de los importantes reinos de Provenza, el Languedoc, Aquitania y el Rosellón, pasan a España.

Los siglos XVI y XVII, cuarta etapa en el desarrollo cofradial-gremial representan en Europa, y desde luego, ya en las posesiones españolas de ultramar, el auge de esas asociaciones voluntarias. La especialización artesanal y laboral creciente durante esa etapa reclama para sí la exclusividad de sus tareas. Toda ciudad funcionaba laboralmente a partir de ellos; los artesanos, comerciantes y profesionales de cada actividad se veían obligados a asociarse gremialmente y profesar su fe a través de las cofradías.

A medida que las cofradías-gremios adquieren más fuerza social y hasta política, exigen esa exclusividad que los hará famosos y, desde luego fuertemente estamentales. Es el colectivo representado en las ordenanzas y estatutos el que rige la vida cotidiana de cada cofrade y agremiado. El individuo queda sometido a la colectividad, ésta le marca sus tareas, sus salarios, sus ritos, sus formas de ascenso a través de las pruebas de conocimientos $\mathrm{y}$, hasta las actividades cotidianas regidas por las obligaciones religiosas de ayuda fraterna y de participación social: matrimonios, entierros y las cada vez más lujosas manifestaciones externas en las procesiones religiosas y desfiles laicos son claras representaciones del sometimiento de lo individual a lo colectivo.

$\mathrm{Si}$ bien el auge de las asociaciones voluntarias fue evidente durante los siglos XVI y XVII y parte del XVIII, el Estado, durante la última etapa del desarrollo cofradialgremial, fue absorbiendo paulatinamente los poderes de las ciudades y con ello empezaron a resentir la influencia de las cofradías-gremios. Poco a poco los comerciantes se hicieron cargo de los gremios artesanales más importantes, en tanto los profesionales se convertían en colegios (Colegios de médicos, de cirujanos, de letrados). La otra cara del gremio, la cofradía fue perdiendo fuerza política y se redujo, hacia finales del XVIII y a lo largo del $\mathrm{XIX}$, a una asociación sólo religiosa, como pervive hasta el presente en algunas ciudades europeas y americanas. 
Estos cambios y la desaparición nominal de la cofradía-gremio se acentuaron a partir del auge del pensamiento ilustrado, de las ideas revolucionarias y del comercio, las cofradías-gremios resultaron ya inoperantes.

Sin lugar a dudas, en todas sus fases la cofradía-gremio mostró como su característica singular, su espíritu particularista, su estrecha e influyente contribución a mantener el orden y su vinculación con la religión, fueron estos rasgos los que le otorgaron la base de su legitimidad. En los países y ciudades en donde existieron, se logró establecer el orden en cuanto a ciertos aspectos del comercio y, muy especialmente, en los servicios de quienes atendían la administración pública y la salud. El control en la preparación de los facultativos en las tareas de la atención a enfermos y heridos, la prescripción y la elaboración de medicamentos adecuados, fueron normados por las cofradías-gremios. Cuando éstas disminuyen su influencia, las tareas que realizaban caen, necesariamente, en manos del Estado, ahora ayudado por el funcionamiento de otro tipo de asociaciones voluntarias, los colegios de profesionistas. Éstos, sin embargo, están ya estrechamente vinculados con las tareas gubernamentales, ya que son aceptados por el Estado y funcionan con su aval, si bien, en el seno de las sociedades civiles.

\section{LA COFRADÍA-GREMIO EN ESPAÑA}

La organización social de asociación voluntaria tuvo alta representatividad en la España medieval. En los siglos XIII y XIV las encontramos funcionando en ciudades de los Reinos de Aragón y Castilla. Santiago Cruz asienta que la más antigua fue la de tejedores, la cual data de la época de Alfonso X de Borgoña, el Sabio (1221-1284), quien ratificó un privilegio otorgado por su antecesor, Alfonso VIII de Borgoña, El Noble (11551214); sin duda debió ser la de la cofradía-gremio de zapateros de Burgos o bien de Aragón para el año de 1211, que, a su vez, hacía referencia a la de albañiles y canteros de Barcelona. ${ }^{4}$ En Segovia las hubo en 1250 y los zapateros de Burgos manifestaron las reglas de su hermandad en 1255. Los barberos de Mallorca habían constituido una cofradíagremio con examinadores a finales del siglo XIV.

En el Reino de Castilla durante los estertores de la Alta Edad Media ya habían adquirido tal desarrollo e influencia como para ser consideradas por los monarcas, como grupos de poder o de presión que podían llegar a mermar la autoridad regia y controlar una parte de la población dentro de lugares, villas y aldeas. Fue así como se las conminó por los reyes a que se limitaran a los fines piadosos fundacionales, los propios de la cofradía. En algunos sitios los monarcas tendieron a disolverlas, pero bastó con la intención; la mayoría de ellas quedaron exclusivamente dedicadas a las obras caritativas con expresa prohibición de realizar actividades que pudieran atentar contra la autoridad real. Frente al desarrollo mercantil y artesanal y las fuertes migraciones urbanas que se dieron en la Alta Edad Media, las cofradías-gremios se volvieron totalmente particularistas y excluyentes. Sus integrantes marginaron a todo artesano que no perteneciera a ellas de tal forma, que en la realidad cotidiana sólo ejercían laboralmente quienes pertenecían a su respectiva cofradía-gremio. Esta temprana actitud, característica de los cofrades-agremiados llevó a disposiciones reales que prohibían su formación sin la dispensa del monarca. Alfonso X en las Leyes del Reino, Ley II, Título VII de la Partida V la deja firmemente establecida. ${ }^{5}$

Desde ese momento tuvieron que acatar la dispensa real, así como la episcopal en su dimensión dual, civil y religiosa, y, en 1473 Enrique IV revocó todas aquellas que no 
hubieran obtenido para su creación la doble autorización. El poder del monarca se cuidó de que los obispos, quienes finalmente controlaban a las cofradías, no tuvieran pleitos entre ellos ni formaran bandos. Esta misma política la continuaron los Reyes Católicos ${ }^{6}$ y por supuesto fue trasladada a las nuevas posesiones americanas. Las disposiciones reales se sucedieron ininterrumpidamente para limitar sus privilegios y ello demuestra que las cofradías-gremios tuvieron la fuerza suficiente para funcionar siempre en apoyo y protección de los cofrades-agremiados. Bajo el mandato de los Reyes Católicos se admitió la personalidad jurídica del gremio reglamentado.

La ciudad española que durante el siglo XVI se convirtió en el centro económico, social, mercantil y cultural de España, Sevilla, es una de las más representativas del auge de las cofradías-gremios. Durante el escenario temporal de la Baja Edad Media sus gremios ya estaban conformados debido a que algunos de ellos se iniciaron, bajo la influencia de los existentes en Aragón y Castilla, durante los años siguientes a la conquista por Fernando III el Santo a mediados del siglo XIII. Sin embargo, sería el auge de la capital andaluza como capital del Reino con su conquistador y bajo el reinado de Alfonso $\mathrm{X}$ y la preferencia que por ella tuvieron los monarcas en general, el que otorgaría las condiciones para el incremento de estas asociaciones voluntarias. En forma paralela al definitivo crecimiento de la ciudad a partir de los viajes trasatlánticos y como consecuencia inmediata de esta situación privilegiada, las cofradías-gremios se consolidan totalmente y adquieren sus matices sociales, económicos, laborales y religiosos. Según Recio sus integrantes constituyen una clase social que se integró por los artesanos, comerciantes e industriales, añadimos nosotros, también por los profesionistas. A medida que la ciudad crecía las cofradías-gremios también se incrementaron y consolidaron y según la fecha de aprobación de sus ordenanzas, el autor que nos sirve de guía, señala su incremento. Así, de tan sólo una cofradía-gremio durante el siglo XIV, aumentan a 50 a lo largo del XV y son 36 nuevas las que aparecen durante el XVI. El total de oficios que cubrieron fue de 80 y en ellos están representadas propiamente la totalidad de actividades artesanales que se podían dar en una población. Todas estas asociaciones realizaban actividades benéficas, culturales, sociales y religiosas: labor asistencial, cultos religiosos en general y del patrón de cada asociación, funcionamiento de hospital, participación en fiestas, atención a los pobres y presos. Es también notable constatar que es durante el auge de la ciudad portuaria del Guadalquivir, el XVI, cuando la diversidad de actividades es mayor y que, a medida que Sevilla pierde su situación preferente a favor de Cádiz, el tipo de actividades se circunscribe a las de asistencia y de culto.

La característica esencial y fundamental de las cofradías-gremios sevillanos es su fuerte carácter de sociabilidad. Desde las primeras de estas asociaciones hasta las actuales cofradías, nos dice Recio, "constituyen una de las más duraderas y firmes asociaciones", en ellas se desarrolla plenamente la sociabilidad, la interacción social, las relaciones interpersonales, generalmente en el ámbito de una igualdad social. En tanto que se dieron, fundamentalmente, entre hombres, con una ingerencia marginal de las mujeres. Esta exclusión de género, no fue privativa de Sevilla, como ya mencionamos, sino generalizada a esta asociación voluntaria, que tuvo como fin sustancial, la protección de la actividad laboral y consecuentemente, de índole masculino.

Como sucedió con la mayoría de las cofradías-gremios europeas, su decadencia y extinción se produjo durante el último tercio del siglo ilustrado. El carácter estamental y cerrado del gremio se llegó a convertir en un impedimento para los avances técnicos e industriales. Sin embargo, la caída no fue tan simple, pero no toca a este trabajo 
estudiarlos, lo que interesa destacar es que, en Sevilla y algunas otras ciudades andaluzas como Córdoba, si bien termina el gremio, su cara religiosa, la cofradía, se mantiene, pero se transforma. Pasa, en términos generales, de ser verticales y más o menos cerradas, a ser verticales abiertas o de barrios. Dejan de agrupar a los ciudadanos que tienen una actividad similar por la de quienes pertenecen a la comunidad de residencia o territorialidad. A pesar de este cambio central, Recio, insiste en la actual pervivencia de algunos de los rasgos de las cofradías-gremiales renacentistas, los que se mantienen en las hermandades. Aún hoy día, se las conoce por el nombre de los gremios que las integraron y que se manifiestan en forma esplendorosa y barroca en la mundialmente conocida Semana Santa Sevillana.

Junto a Sevilla, su hermana en el tránsito del Guadalquivir, Córdoba es el otro ejemplo singular de la existencia temprana y de la pervivencia de las cofradías-gremios. También en ella las asociaciones voluntarias de artesanos como parte de la vida espiritual y laboral, giraron en torno a la Iglesia y dentro de ella las cofradías y hermandades se fundaron y se consolidaron. Las hubo de dos tipos, las que contaban con un hospital para la atención de los cofrades enfermos agremiados, denominadas cofradías hospitalarias y que representaban a las asociaciones más fuertes y cohesionadas. Junto a ella figuraron las no hospitalarias, más débiles y con menor número de cofrades. ${ }^{7}$

\section{LA COFRADÍA-GREMIO DE BARBEROS, CIRUJANOS, FLEBOTOMIANOS Y MÉDICOS EN ESPAÑA}

Dentro del marco de la conformación de la asociación voluntaria, una de las que más importancia social tuvo por sus repercusiones en la vida colectiva, fue la que agrupó a quienes se ocuparon en la atención a las enfermedades. Desde finales de la Alta y principios de la Baja Edad Media la integraron todos aquellos que, en una forma u otra, atendían a los enfermos de cada comunidad. Ocuparon lugar en ella los siguientes facultativos: Los barberos, quienes no sólo atendían las barbas y rasuras, también los problemas dentarios; los flebotomianos, quienes realizaban, preferentemente, las sangrías; los algebristas, quienes componían los huesos; los cirujanos, quienes, como ya sabemos, tenían a su cargo toda enfermedad externa y se internaban en el cuerpo humano para extraer tumores y cálculos o para realizar las disecciones con fines docentes $o$ anatomopatológicos. Los médicos, quienes si bien no compartían con los anteriores el mismo status profesional y social, seguramente se unieron a la cofradía-gremio con la intención de salvaguardar su labor frente a la intrusión de extraños.

La referencia más antigua y el punto de partida de todas estas asociaciones provienen de la de León en donde antes de finalizar el siglo XIV, se constituyó una cofradía de cirujanos. De acuerdo al destacado historiador de la medicina, don Agustín Albarraicín citado en El Médico interactivo. Diario electrónico de Sanidad ${ }^{8}$, esta cofradía fue confirmada por don Juan I de Trastámara (1358-1390) en 1392; es posible que se trate de un error de impresión, ya que en esa fecha, Juan I había fallecido, es posible que la confirmación se diera en 1390 o bien la otorgara su sucesor e hijo don Enrique III (13791406). Sin embargo, la diferencia no es significativa, en tanto que sí lo es lo temprano de la presencia de la asociación voluntaria en esa ciudad, confluencia de los caminos que cruzaban Castilla. Entre otros, en forma muy destacada el "Camino de Santiago"; sin duda, fue por esta vía, por la que transitó hacia España la idea de la agrupación de personas con una similar ocupación que tanto auge tenía ya en Francia. Si bien hoy contamos con 
confirmación cronológica de la presencia de esta cofradía, el mismo autor señala que "todavía antes, los barberos y cirujanos mallorquines habían constituido ya un colegio con examinadores". Sin duda, se está refiriendo a una cofradía o gremio, ya que para ese escenario no figuraban aún los colegios como tales. Lo importante es el señalamiento de que en la relativamente lejana isla balear, los facultativos de la salud, se habían asociado. Si bien no tenemos preciso el nombre de estas primeras asociaciones, es muy probable que todas ellas obedezcan a la denominación de "San Cosme y San Damián", alguna añadida o precedida por San Lucas. Fueron los dos santos médicos asiáticos los que atrajeron por su propia historia el patronazgo de todos los que se ocuparon de la enfermedad y salud.

Como ya vimos anteriormente, los años del siglo renacentista español, el XV, vio surgir en Europa y también en España, numerosas asociaciones similares. En Barcelona conocemos la existencia en 1408 de una cofradía de cirujanos y barberos, la cual fue elevada a la categoría de colegio en 1485 por Alfonso V de Trastámara, llamado "El Magnánimo" (1396-1458). En el mismo Reino de Aragón, en la ciudad de Valencia encontramos otra cofradía-gremio para la cual se aprobaron sus constituciones como colegio en 1443. En Huesca la Cofradía de San Lucas y los Santos médicos Cosme y Damián agrupa a "físicos, cirujanos y especieros o meges, apotecarios e cirúgicos", o sea a los médicos, cirujanos y farmacéuticos. Sus estatutos fueron aprobados en junio de $1480 \mathrm{y}$ en ellos se norman varios aspectos: tratar a los enfermos, comportamiento en los hospitales, la jerarquía entre los diferentes facultativos: médicos, cirujanos y boticarios; las obligaciones religiosas y las penas por no obedecer las regulaciones. Tempranamente se convirtió en colegio o bien, pienso yo, se confirmaron sus ordenanzas, por el rey Fernando el Católico en $1508 .^{10}$

Los ciudadanos de Zaragoza hacen lo mismo en 1495 y bajo la misma advocación. Sus constituciones son explícitas: "Ningún físico ni cirujano del Colegio de San Cosme y San Damián concurra, ni pueda concurrir dentro de la ciudad de Zaragoza en la práctica tanto de medicina como de cirugía, con otro médico o cirujano, aunque fuese graduado en el estudio general, sin que sea cofrade y tenga juradas las ordenaciones, bajo la pena de 20 sueldos". 11

En el Reino de Navarra, aún independiente, la primera cofradía sanitaria aparece en Pamplona en 1496, pero también las hubo en Tudela y Estella, aunque en un contexto temporal más tardío. En la ciudad capital, el médico, el cirujano y el boticario reales se reúnen en enero y redactan las ordenanzas que regirán en adelante a todo aquel barbero, cirujano, médico o boticario que desee ejercer en Pamplona. La asamblea que creo la cofradía tuvo lugar en el Monasterio Carmelita de Santa María del Carmen y se inició con 14 congregados a los que posteriormente se añadirían tres más. En la formulación de las ordenanzas se seleccionó también como intercesores divinos a San Cosme y San Damián y se asentó en la capilla del mismo nombre del monasterio carmelita. Fueron confirmadas por el rey en junio de 1496.

Las ordenanzas son un fiel reflejo de las que rigieron, en términos generales, a todas estas cofradías. Se designan sus integrantes definitivos, diecisiete; en el caso, un médico, cinco "apotecarios" o boticarios, dos cirujanos y nueve barberos. El predominio numérico de éstos señala precisamente esa misma situación imperante en las ciudades. Las obligaciones que contraían los agremiados giraban, tanto en torno a las de carácter religioso, como a las del ejercicio y la formación. Ningún agremiado podría practicar en Pamplona y tres a cuatro leguas en derredor, si no estuviere graduado y "examinado por los dichos físicos y Diputados que de la arte son”. Además requerirían de la licencia de los 
diputados y deberían cubrir sus cuotas a la cofradía. En caso de que pretendieran ejercer sin conocimientos probados, serían multados con 15 florines, de los cuales 5 se darían al delator y 10 ingresarían a la tesorería de la cofradía. En caso de reincidencia se le correría de la ciudad y se le confiscarían todos sus bienes. ${ }^{12}$ Se normó el ejercicio de las curaciones y por lo que tocaba a los cirujanos, los "maestros", éstos en caso de requerir la ayuda de un cofrade por lo peligroso de la cura, "debe pagarle de sus honorarios" y si el paciente no pudiera cubrir sus honorarios, el cofrade debía continuar la cura. La cláusula que establecía la apertura de tienda - caso de los barberos y boticarios- se requería, no sólo conocimiento, también "antecedentes morales intachables", con ello se está dando paso a los que más tarde sería la "limpieza de sangre" que se exigirá a todo candidato a boticario, cirujano y médico.

La cofradía de Pamplona permaneció muy similar una vez que la ciudad se unió al Reino de Castilla y lo que es más interesante, a partir de 1519 quedó establecido que quienes pretendieran ejercer su "arte", deberían exhibir sus títulos ante el Consejo Real. Por su parte la cofradía exigió se respetaran sus privilegios en el sentido de que los examinadores de sus candidatos fueran sólo los miembros de ella y, consecuentemente, no aceptaron la ingerencia de protomédicos externos.

En Zaragoza, la cofradía existía desde 1455 y estuvo situada en el Hospital de Nuestra Señora de Gracia hasta parte del siglo XIX de donde se transformó en Colegio de Médicos y dio paso a la fundación de la Facultad de Medicina. ${ }^{13}$

El siglo XVI es testigo de cofradías de San Cosme y San Damián en otras ciudades; en Valladolid quedó situada en la parroquia de Santiago y se aprobaron sus ordenanzas en $1578 .{ }^{14}$ En tanto que en Madrid, los médicos, cirujanos, flebotomianos, albéitares y barberos se congregaron en 1583, desde luego, también bajo la advocación de San Cosme y San Damián. Sus iniciales ordenanzas se añadieron en 1611, para entonces estaba sita, y es probable que desde su fundación, en el monasterio y convento agustino de San Felipe. En ella se reunieron los mayordomos, diputados, examinadores y cofrades y completaron algunas ordenanzas, especialmente las que tocaban a los barberos y acordaron respetarlas y guardarlas, no sólo para los miembros de esa cofradía, sino para todos los barberos residentes en la corte. ${ }^{15}$

En Teruel los médicos, boticarios y cirujanos se reunieron en septiembre de 1634 para redactar las ordenanzas de su cofradía, desde luego, bajo la advocación de San Cosme y San Damián e instituida en el claustro de la Parroquia del Señor San Pedro. Un año después el rey Felipe IV (1605-1665) acepta y aprueba las ordenanzas del Syndici Collegi Sanctorum Cosme et Damiani, civitas Turoli. Para mediados del siglo XVIII la cofradía, siguiendo la norma imperante en el siglo ilustrado, se había transformado en Real Colegio de Médicos, Boticarios y Cirujanos, el cual tenía capilla y sepulcro en el claustro del Obispado. ${ }^{16}$

Del Sur español poco hemos averiguado sobre esta cofradía, pero sí sabemos que en Sevilla, durante el siglo XV la había de barberos, seguramente también flebotomianos y que realizaban labor hospitalaria y de culto. Los boticarios como cofradía existieron a partir del siglo XVI y tenían actividades de labor asistencial, de culto, de hospital y, desde luego, de cofradía. Las primeras noticias acerca de la de San Cosme y San Damián la encontramos en una relación de hermanos fundadores datada en 1512 que se encuentra en el fondo documental del Hospital del Salvador, vulgo de las Bubas. ${ }^{17}$ En la actualidad la hermandad, que como tal se ha conservado, asiste de forma corporativa a la Procesión del Corpus Christi que se desarrolla por las calles de Sevilla.

En la capital andaluza existieron durante el siglo XVI dos hospitales bajo la misma advocación, el Hospital de San Cosme y San Damián u Hospital del Salvador, 
(vulgo de las Bubas), situado en la céntrica Plaza del Salvador, hacia el siglo XVII paso a manos de los juaninos. El segundo fue el Hospital de San Cosme y San Damián, mejor conocido como Hospital de los Inocentes, con atención a los enfermos mentales y absorbido por el Hospital Real de Sevilla. ${ }^{18}$

Es casi seguro que las cofradías de facultativos de la salud existieron en la mayor parte de las ciudades españolas, sin embargo, nosotros sólo hemos podido rescatar las mencionadas. No debemos olvidar que, a la fundación del Real Tribunal del Protomedicato por los Reyes Católicos, este organismo vino en mucho a sustituir las funciones de reglamentación y de control del ejercicio de quienes atendían la salud y enfermedad. De aquí, que en muchas ciudades de los Reinos de Castilla y Aragón o aquéllas que no gozaban de privilegios forales, la cofradía pudo pasar a un plano menos importante, pero conservando vigente su aspecto religioso.

\section{4. ¿QUIÉNES FUERON SAN COSME Y SAN DAMIÁN?}

Llegaron a ser de tanta importancia en el culto europeo que su origen se lo disputan Arabia, Grecia y Roma. La leyenda cristiana atribuye su lugar de nacimiento al primero de esos sitios; su progenitor fue originalmente pagano y convertido al cristianismo por la influencia de una esposa cristiana. Los jóvenes, seguramente, muy similares en edad, alguna leyenda los considera gemelos, estudiaron medicina en Siria y ejercieron su profesión en la ciudad de Egea sobre la costa de Cilicia, actualmente Anatolia. Se distinguieron por no cobrar a los enfermos, de donde hayan recibido el sobrenombre de anargyroi (sin dinero o sin plata) que se otorgaba a todo aquel que no aceptaba pago alguno por sus servicios. Sus curaciones estaban basadas en la ciencia médica del momento, el siglo III d.C., pero también se les menciona como médicos milagrosos. La más destacada fue la de carácter quirúrgico, el trasplante de la pierna del cadáver de un negro para injertarla en un enfermo blanco recién amputado. Esta operación se volvió una de las imágenes más dibujadas por los artistas de diferentes época. San Cosme y San Damián, junto con otros tres hermanos, fueron víctima de la persecución de cristianos del emperador Diocleciano en el año de 303 en la provincia de Cilicia. Terminar la vida de los dos médicos y de sus tres hermanos no resultó tarea sencilla para su perseguidor, el pretor romano Licias. Primero los mandó asaetear y apedrear, pero flechas y piedras no los tocaron y se volvieron contra los verdugos; posteriormente fueron atados de pies y manos y arrojados al mar, pero las aguas no los recibieron y los regresaron ilesos a la playa. Luego intentaron quemarlos, las llamas los respetaron. Desesperado, el pretor romano, mandó decapitarlos, ahora junto con sus tres hermanos. Esta fue la forma de su muerte y su sepultura quedó en la población de Cirruhs en donde la visitó el emperador Justiniano I en reconocimiento a su milagrosa curación.

Sus curaciones normales, pero especialmente las milagrosas, tanto en vida como después de fallecidos, su difícil muerte y su enorme popularidad al invocarlos en ocasión de las pestes, les dieron la gran fama que se extendió, primero, por el mundo romano, después en todo el mundo occidental. Ya para principios del siglo V se habían consagrado a los dos médicos numerosas iglesias; dos de ellas en la antigua Constantinopla, una más en Roma que se dedicó en su honor el 27 de septiembre por el Papa Félix (526-530) y es esa fecha la que se consagró como su día festivo, al cambio del calendario se cambió al 26. 
Numerosas poblaciones españolas dedicaron a los santos médicos sus iglesias y los convirtieron en sus patronos; en la actualidad aún se conservan como tales. Alfonso III de Aragón, apodado "El Liberal o el Franco" (1265-1291) da testimonio de la existencia del Monasterio de San Cosme y San Damián en Abeliar, a orillas del río Torio en territorio de León. ${ }^{19}$ La Colegiata de San Cosme y San Damián en la población de Covarrubias cercana a Burgos conserva una de las pinturas más famosas de los santos, el óleo que pintó Pedro Berruguete (1450-1504). ${ }^{20}$ En el Alto Aragón existe un Santuario dedicado a los santos médicos $^{21}$; La Rioja cuenta, cerca de Logroño, con una parroquia dedicada a ellos. ${ }^{22}$ Así podríamos continuar un largo repaso de las numerosas iglesias y de las fiestas patronales que llevan la advocación de San Cosme y San Damián, pero no es esa la intención de este trabajo, tan sólo dejar constancia de la enorme popularidad de los caritativos médicos y explicarnos el por qué, socialmente, los facultativos de la enfermedad y salud los escogieron como sus protectores y les dedicaron sus cofradías.

La iconografía los representa con vestiduras especiales, la túnica y el gorro característicos de los médicos, en las manos llevan, indiferentemente, instrumentos de su profesión: un maletín de cirugía, un mortero, una caja de medicinas, espátula, un orinal. ${ }^{23}$ Adicionalmente, sus nombres, derivados del griego, significan, Cosme: "adornado, bien presentado, bello" y Damián: "prudente, domador".

\section{LAS COFRADÍAS-GREMIOS EN LA NUEVA ESPAÑA Y LA COFRADÍA DE SAN COSME Y SAN DAMIÁN. ${ }^{24}$}

El paso de los artesanos y profesionistas, barberos, médicos, boticarios y cirujanos, fue casi simultáneo a la conquista española del territorio mexicano. Ellos trajeron consigo las organizaciones sociales en las que se habían formado y las implementaron con inusitada rapidez en el nuevo ámbito social. Su conformación no fue diferente a las originales españolas; sin embargo destacan las cofradías-gremios novohispanos por varias características esenciales.

Las cofradías-gremios se inician fundamentalmente en su faceta religiosa como parte intrínseca de la inicial etapa de evangelización. Junto, o casi, al establecimiento de las parroquias e iglesias se instalaron las cofradías, también consideradas como congregaciones eclesiásticas de fieles cristianos, principalmente seglares. Estuvieron canónicamente instituidas y supervisadas y controladas por el superior eclesiástico competente para promover, por medio del culto divino, la caridad y las buenas obras para con el prójimo.

Al paso de unos cuantos años se convirtieron en la forma de organización por nosotros conocida en la cual se expresó la sociabilidad de la población en sus diferentes estratos étnicos. Sus miembros definieron espacios que propiciaron la emergencia de identidades y ocupaciones, la formación de una élite urbana de castas e inclusive de esclavos, ya que hubieron cofradías-gremios de mulatos, mestizos, indios, y, por supuesto, españoles.

Entre sus características específicas al contexto virreinal se destacan, frente a las de la península, las siguientes:

1.- Su establecimiento como un acto de jurisdicción episcopal, enteramente reservado al obispo, y, de acuerdo a los decretos del Concilio de Trento y del III Concilio Mexicano la elección de sus dirigentes y la administración de sus finanzas estuvieron supervisadas por el párroco. 
2.- Sin duda al tratarse de cofradías-gremios y a la existencia del Patronato Real, las cofradías, como organizaciones eclesiásticas, tuvieron que cumplir con la legislación civil, que tenía prioridad sobre la legislación eclesiástica. En 1591 y 1618 el rey otorgó a los obispos la facultad de fundar cofradías para los indios y en 1682 extendió esta facultad para formar asociaciones pías para los españoles y castas.

3.- Las cofradías que no eran de españoles estaban aún bajo mayor control, según las Leyes de Indias: “....cuando se juntaren las cofradías de indios o negros asista con ellos el prelado de la casa o la persona que él nombrare..."

4.- Contribuyeron a mantener la cohesión social comunitaria, fuera en las ciudades o en las zonas rurales, en donde funcionaron numerosas cofradías-gremios de indios, no sólo con ocupaciones similares, también sólo como vecinos. En esos escenarios geográficos fueron las escuelas religiosas las que ayudaron a preparar a los jóvenes indios para participar en ciertas actividades de las cofradías, inclusive figurar como sus mayordomos. ${ }^{25}$

5.- Los miembros de las cofradías-gremios llegaron a desarrollar una estrecha vinculación con los hospitales en donde se brindaba el auxilio a los enfermos. Lo encontramos tanto en las grandes ciudades, como en las zonas rurales de Michoacán y Jalisco o en el llamado Camino de Tierra Adentro o de la Plata, el que corría de la Ciudad de México al lejano septentrión. Los cofrades tenían la obligación semanal de turnarse para cuidar a los enfermos, de ahí se les llamó "semaneros".

6.- La característica más destacada de las cofradías-gremios novohispanos fue su papel crucial como otorgantes de los créditos que apoyaban la economía de los habitantes de las comunidades.

Dagmar Bechtloff ${ }^{26}$ hace notar que, si bien las primeras cofradías-gremios estuvieron sujetas a los ideales cristianos, a medida que transcurría el tiempo y contaban con elevados ingresos por concepto de cuotas, donaciones y actividades artesanales, llegaron a desarrollar una importante función en el desarrollo económico del Reino. Sin perder su contenido religioso y cristiano, se constituyeron en fuertes empresas de préstamo.

En el caso específico de la asociación voluntaria de profesionales y especialmente en la Nueva España hemos podido comprobar una característica más, tal vez especial (no parece ser el caso de España) y que consiste en que no necesariamente tuvo en su estructura el agregado del gremio. Así, se presentaron, que hayamos podido identificar, dos formas:

A.- Cuando las cofradías eran puramente religiosas y con carácter vecinal o territorial, sus miembros no estaban unidos por la pertenencia a una misma actividad, y, por lo tanto, no tenían necesidad de agruparse en un gremio para los fines que este tipo de asociación tenía establecidos.

B.- Pero, también tenemos el caso, tal vez único, de quienes si bien realizaban actividades iguales o similares, éstas no estuvieron sujetas a una de las características esenciales del gremio, la jerarquización de posiciones para la adquisición de conocimientos y el ejercicio de la actividad. Si bien hubo agregación de intereses en torno a la protección frente al intrusismo, no cumplieron con el requisito del aprendiz, el oficial y el maestro en el estricto sentido en el que se dio entre los artesanos y los obreros agremiados. En este 
segundo tipo, especialistas en la enfermedad y letrados, ciertamente sí adquirían algunas habilidades, expresamente la del barbero, flebotomiano o cirujano, a través del aprendizaje durante varios años bajo la supervisión o al lado de un personaje experimentado $\mathrm{y}$, en algunos casos examinado, la jerarquía ocupacional no estuvo fijada por ordenanzas o cuando menos no las hemos localizado. En tanto que las relaciones sociales, asistenciales y religiosas sí se establecieron dentro de ese tipo de cofradías.

De lo anterior proponemos como hipótesis, limitada al caso de las profesiones de la salud y la enfermedad debido al mayor conocimiento que tenemos de su estructura y funcionamiento, que sus integrantes se asociaron en cofradías, pero no en gremios. A partir de esta propuesta afirmamos:

En la Ciudad de México tenemos localizada con toda precisión la existencia de la cofradía de San Cosme y San Damián. ${ }^{27}$ Desde muy temprano en la historia virreinal se promovió la devoción a esos santos médicos a través de la fundación de una ermita y un hospital a su nombre, que se cree haya sido realizada por el primer arzobispo, fray Juan de Zumárraga. Con el tiempo se convirtió en la Iglesia de San Cosme y San Damián, actualmente aún abierta a la devoción pública.

De la cofradía como tal, según Bazarte, tenemos las primeras noticias hasta finales del siglo XVII, 1692; sin embargo, barberos flebotomianos, cirujanos y médicos los hubo desde los años de la conquista armada. Si bien la autora no da cuenta en fechas anteriores, sí tenemos documentado que el destacado médico de la segunda mitad del siglo XVI, Pedro López, fundador de dos hospitales, perteneció a la cofradía de San Cosme y San Damián. Él mismo los asienta así en su testamento en una de sus cláusulas. ${ }^{28}$

La cofradía de la Santísima Trinidad funcionó desde 1580 asociada a la de Roma del mismo nombre y con los mismos amplios privilegios de otorgar indulgencias a sus agremiados. En 1585 pasó a ser una archicofradía que con el tiempo, siglos XVII y XVIII, reuniría en su seno el mayor número de cofradías de la capital novohispana. Entre ellas, por supuesto, la de San Cosme y San Damián. Ésta por ordenanzas, quedó limitada a 33 cofrades, número que aparece generalmente en las cofradías que pertenecieron a la archicofradía. Con el tiempo el prestigio de ambas asociaciones y el crecimiento en el número de los barberos, cirujanos y demás agremiados, redundó en la creación de una cofradía paralela, la del Santo Cristo de la Salud. Tuvo la característica que aceptó "personas de todos oficios, calidades y sexos". ${ }^{29}$ Las dos compartieron en la Iglesia de la archicofradía, un altar común y una vez que las Cortes de Cádiz dispusieron la suspensión de las cofradías, la de San Cosme y San Damián se unió a la del Cristo de la Salud y sobrevivió hasta mediados del siglo XIX, como sucedió en Sevilla y Córdoba.

Para 1783 se fundó una cofradía paralela, tuvo su sede en el templo del Sagrario Metropolitano, y según Bazarte, se denominó Lacayos y Esclavos del Santísimo Sacramento, probablemente compuesta por médicos y cirujanos, ya que para ese escenario temporal, los segundos habían ascendido en status profesional y social a raíz de la creación de la Real Escuela de Cirugía.

La devoción a los santos médicos, patronos de los cirujanos y demás facultativos de la salud y la enfermedad, en el presente tiene representación en diferentes iglesias mexicanas. En la Catedral de la Ciudad de México existe la capilla de San Cosme y San Damián, ubicada a la derecha del Altar del Perdón, la cual perteneció a la cofradía-gremio de los artesanos y mercaderes de gorras y de la seda llamada de San Francisco, hermandad de San Cosme y San Damián ${ }^{30}$. Era frecuente que los gorreros asumieran el mismo nombre de la cofradía de los cirujanos y médicos, precisamente, por ser quienes elaboraban los 
capelos especiales que usaban aquellos. En la ciudad de Oaxaca, a semejanza de Sevilla, se fundó desde mediados del siglo XVI el Hospital de San Cosme y San Damián, también conocido como Hospital Real y fue el precedente de la Iglesia de la misma advocación que persiste hasta la actualidad. En ella se celebra la fiesta patronal el 26 de septiembre con oficios religiosos y procesión en torno al templo.

Las cofradías-gremios y las cofradías fueron, en ambos casos, capaces de mantener en Europa y en América la cohesión social, religiosa y laboral de quienes se dedicaban a una misma actividad. En el caso novohispano, se convirtieron en una poderosa fuente de poder económico, vía los préstamos no sólo a los agremiados, sino a instituciones e individuos independientes. Persistieron oficialmente hasta el inicio del siglo XIX en su calidad conjunta de gremios ocupacionales y asociaciones religiosas, $\mathrm{y}$, muchas de ellas han sido capaces de mantenerse hasta la actualidad en su carácter estrictamente religioso, pero con una fuerte capacidad de sociabilidad que trasciende las fronteras sociales y políticas.

\section{NOTAS}

${ }^{1}$ Cfr. Artículo "Gremios" en la Enciclopedia Internacional de las Ciencias Sociales, Aguilar, Madrid, 1992, tomo 5, p. 203.

${ }^{2}$ SANTIAGO CRUZ, F. (1960): Las Artes y los Gremios en la Nueva España, México, Ed. Jus, S. A.

3 RECIO LAMATA, J. P. Los Gremios en www.elsanedrín.com/gremios/gremios2.htm [Consulta 28/04/2009]

${ }^{4}$ Ibídem, p. 2.

${ }^{5}$ Ibídem, p. 11.

${ }^{6}$ GUEVARA PÉREZ, E. (2004): Historia de la Semana Santa de Madrid, Madrid, Silex, pp. 23-24.

${ }^{7}$ CÁMARA AROCA, M. (1985): 'Orígenes de las Cofradías: Gremios y Hospitales', Alto Guadalquivir, Cajasur,www.silencioblanco.org/ARCHIVO/ALTO\%20GUADALQUIVIR\%201985.htm

${ }^{8}$ www.Medynet.com/elmedico/informe/colegiosmedicosi.htm [Consulta 26/04/2009].

${ }^{9}$ Ibídem.

${ }^{10}$ Ilustre Colegio Oficial de Médicos de Huesca, historia en, www.colmedhuesca.com/cmh/historia. asp [Consulta 25/02/2009]

${ }^{11}$ Ibídem.

12 ADANERO, C. Notas de Historia de la Farmacia, Cofradía de San Cosme y San Damián en Pamplona en www.historiafarmacia.blogspot.es/1198776660/cofradía-de-san-cosme-de-pamplona(1496) [Consulta 25/02/2009].

${ }^{13}$ Colegio Oficial de Médicos de Zaragoza: Conocer el Colegio, Historia. www.usuaruis.com/ib306708/colegios5.htm [Consulta 20/02/2009]

${ }^{14}$ EGIDO, T. 'Religiosidad popular y asistencia social en Valladolid: Las cofradías marianas del siglo XVI’ en Estudios Marianos, 45, 1980, p. 21.

15 'Reforma de las ordenanzas de los barberos y cirujanos de Madrid. Archivo Histórico de Protocolos de Madrid, Protocolo 3.021, Juan López, fols. 443-445v., Madrid, 17 de marzo de 1661. www.gremios.ih.csic.es/artesanos/index.php.option=com_content\&task=view\&id $=58 \&$ itemid $=26$

[Consultado 20 de febrero del 2009]

${ }^{16}$ Colegio Oficial de Médicos de Teruel: Historia del Colegio, los orígenes.

www.comteruel.org/web/colegio/historia.hyml

${ }^{17}$ El fondo documental del Hospital de las Bubas de Sevilla, esta depositado junto con otros tantos (Hospital de la Misericordia, Hospital de las Cinco Llagas, Hospital de San Lázaro, etc.) en el Archivo de la Diputación Provincial de Sevilla; Vid. BARRIGA GUILLÉN, C., HEREDIA HERRERA, A., SILES 
SATURNINO, R. y ZAHINO PEÑAFORT, L. (1997): Hospitales y Centros Benéficos sevillanos. Inventario de sus fondos, Diputación de Sevilla. En el legajo $\mathrm{n}^{\circ} 23$ del fondo documental del Hospital de las Bubas y bajo la denominación de documentos sueltos (1504 y ss.) hay una anotación que dice así: Hay una relación de 1512 de los primeros hermanos que instituyeron la cofradía de San Cosme y San Damián. Información gentilmente proporcionada por el Prof. Antonio José López G. de la "Universidad Pablo de Olavide" de Sevilla.

${ }^{18}$ BELLO LEÓN, J.M. y CARMONA RUÍZ, M. A., 'Ordenanzas del Hospital Real de Sevilla (Años 1500, 1526) en Miscelánea Medieval Murciana, Vol. XXI-XXII. Años 1997-1998, pp. 9-42.

${ }^{19}$ www.uah.es/historia1/carlossaez/Regestos/901_901_m.htm [Consultada el 10 de febrero del 2009]

${ }^{20}$ www.fisterra.com/human/3arte/pintura/milagro_sancosme.asp [Consultado el 28 de mayo del 2009]

${ }^{21}$ www.liesa.info/guara/sancosme/santuar.htm [Consultado el 28 de mayo del 2009]

${ }^{22}$ www.groups.msn.com/varea [Consultado el 28 de mayo del 2009].

23 www.historiarte.net/iconografia/cosme.html [Consultada 20 de febrero del 2009]

${ }^{24}$ Para este trabajo, tan sólo proporcionamos los datos más significativos sobre este tipo de asociación voluntaria. En el completo, del cual esté es sólo una versión resumida, se dedica un espacio mucho más amplio a la Nueva España como corresponde a una obra que se ocupa de tema durante la etapa virreinal mexicana.

${ }^{25}$ Dorothy Tanck de Estrada, Pueblos de Indios y educación en el México Colonial, 1750-1821, El Colegio de México, Centro de Estudios Históricos, México, 1999.

${ }^{26}$ BECHTLOFF, D. (1966): Las cofradias en Michoacan durante la época de la colonia: la religión y su relación política y económica en una sociedad intercultural, México, El Colegio de Michoacán y El Colegio Mexiquense.

${ }^{27}$ BAZARTE MARTíNEZ, A. (1999): 'La Cofradía de Cosme y Damián en el siglo XVIII’ en Fuentes Humanísticas, Departamento de Humanidades, UAM, Atzcapotzalco, Año 10, Primer Semestre de 1999, No. 18 , pp. 47-57.

${ }^{28}$ FERRERIO N. y SIGAUT, N. (2005): 'Testamento del "Fundador” Dr. Pedro López. Documentos para la Historia del Hospital de San Juan de Dios' en Historia Mexicana, julio-septiembre, año/vol. LV., número 001, El Colegio de México, A. C. México.

${ }^{29}$ Ibídem, p. 50 y Archivo General de la Nación, Bienes Nacionales, vol. 197, exp. 7

${ }^{30}$ María del Socorro Sentíes, 'Capilla de San Cosme y San Damián, retablo centro, Dos médicos prodigiosos en la Catedral de México' www.desdelafe.com.mx/index2.php?option=com_contenido $\& d p \_p d f=1 \&$ id $=1629$

\section{Breve currículo:}

\section{María Luisa Rodríguez-Sala Gomezgil}

Investigadora del más alto nivel en el Instituto de Investigaciones Sociales de la Universidad Nacional Autónoma de México (UNAM) desde 1959. Tiene los grados de licenciada en Ciencias Sociales y maestra y doctora en Historia por la misma universidad. Ha impartido docencia en diferentes instituciones mexicanas y ha sido investigadora invitada en distintas universidades españolas. Durante 2006 recibió invitación de la Universidad de Castilla-La Mancha en Toledo, Rey Juan Carlos de Madrid y Universidad Pablo de Olavide de Sevilla, ha participado en numerosas reuniones académicas nacionales e internaciones. En su obra más reciente figura como coordinadora y autora de la Serie Los Cirujanos de la Nueva España, de la que han aparecido varios volúmenes. 